\title{
PENGARUH MODELLING THE WAY TERHADAP KEMAMPUAN MENULIS TEKS CERITA FABEL SISWA SMP
}

\author{
Oktavia Lestari P. \\ Universitas Muhammadiy ah Sumatera Utara \\ email: oktavialestari1990@y ahoo.com
}

DOI: $\underline{10.26858 / \text { retorika.v 10i2.4854 }}$

\begin{abstract}
Effect of Modeling the Way on Ability to Write Text of Fables of Junior High School Students. This study aims to determine the effect of modeling model learning the way to the ability to write text stories fable junior high school students. The research used quantitative approach with experiment method. The population of this study is the students of class VIII SMP Muhammadiyah 3 Medan, amounting to 50 people. Data collection is done through learning result test. The results showed the ability to write fable story text by using modeling modeling the way in experiment class good categorized and there is influence model of learning modeling the way to the ability of writing fable story text by grade VIII student of SMP.
\end{abstract}

\begin{abstract}
Abstrak: Pengaruh Modeling the Way terhadap Kemampuan Menulis Teks Cerita Fabel Siswa SMP. Penelitian ini bertujuan untuk mengetahui pengaruh model pembelajaran modeling the way terhadap kemampuan menulis teks cerita fabel siswa SMP. Penelitian menggunakan pendekatan kuantitatif dengan metode eksperimen. Populasi penelitian ini adalah adalah siswa kelas VIII SMP Muhammadiyah 3 Medan yang berjumlah 50 orang. Pengumpulan data dilakukan melalui tes hasil belajar. Hasil penelitian menunjukkan kemampuan menulis teks cerita fabel dengan menggunakan model pembelajaran modeling the way pada kelas eksperimen berkategori baik dan ada pengaruh model pembelajaran modeling the way terhadap kemampuan menulis teks cerita fabel oleh siswa kelas VIII SMP.
\end{abstract}

Kata kunci : modeling the way, menulis, teks cerita fabel

Tarigan (2005:1) mengemukakan keterampilan berbahasa mencakup empat aspek, yaitu keterampilan menyimak, keterampilan berbicara, keterampilan membaca, dan keterampilan menulis. Empat keterampilan berbahasa tidak dapat dipisahkan antara satu dengan yang lainnya. Jika salah satu dari keempat keterampilan tidak dikuasai, maka kemampuan seseorang dalam bidang bahasa belum maksimal. Dari keempat keterampilan di atas, keterampilan menulis merupakan salah satu kemampuan berbahasa yang harus dimiliki oleh setiap orang.

Keterampilan menulis merupakan suatu proses yang kreatif sebab kegiatan menulis, bukan hanya memperkuat ingatan, tetapi memberikan proses berpikir, ketenangan, ketelitian, kehalusan, dan kekayaan yang tidak mungkin dicapai jika tidak ada keterampilan menulis. Menulis merupakan suatu kegiatan yang produktif dan ekspresif. Tarigan (2005:4) mengemukakan bahwa kegiatan menulis bertujuan untuk mengungkapkan fakta-fakta, pesan sikap dan isi pikiran secara jelas, dan efektif kepada para pembacanya.

Kebiasaan menulis mengantarkan manusia pada kearifan mengungkapkan gagasan secara sistematis apa yang dilihat, didengar, dan dibacanya. Seorang guru perlu menyadari bahwa dalam proses pembelajaran menulis masih ditemukan kesulitan, siswa merasa sulit menuangkan ide, gagasan atau pikiran yang disertai imajinasi serta pemahaman siswa yang masih kurang terhadap materi sehingga mengakibatkan proses belajar yang tidak berjalan lancar.

Salah satu upaya untuk menghindari kesulitan dalam pembelajaran, yaitu dengan menggunakan media pembelajaran. Media memiliki fungsi yang sangat penting. Secara umum fungsi 
media adalah sebagai penyalur pesan. Media pengajaran dapat mempertinggi proses belajar siswa dalam pengajaran yang pada gilirannya dapat mempertinggi hasil belajar yang dicapai (Sudjana, 2008:2).

Penyebab terjadi kesulitan dalam pembelajaran salah satunya penyampaian materi yang membosankan dan media pembelajaran yang kurang bervariatif terutama dalam penyampaian materi teks cerita fabel. Guru bahasa dan Sastra Indonesia masih mengajar dengan menyuruh siswa membaca teks fabel tersebut dan mencatatnya kembali. Seharusnya siswa tidak hanya mampu membaca teks cerita fable, tetapi hendaknya mampu juga dalam menulis dan membuat teks cerita fabel yang telah dibacanya atau didengarnya sesuai dengan struktur teksnya dan dengan menggunakan bahasa sendiri, yang merupakan tuntutan dalam kurikulum 2013 di SMP bidang studi Bahasa dan Sastra Indonesia di kelas VIII.

Cara belajar yang diubah menjadi kreatif dan penggunaan media akan menumbuhkan keinginan serta daya kreativitas siswa. Oleh karena itu, berdasarkan latar belakang masalah tersebut peneliti tertarik untuk melakukan penelitian dalam meningkatkan kemampuan menulis kembali teks cerita fabel melalui media audiovisual siswa kelas VIII SMP Muhammadiyah 3 Medan. Sesuai dengan batasan masalah ini, penelitian menetap-kan rumusan masalah sebagai berikut. Bagaima-nakah kemampuan menulis teks cerita fabel de-ngan menggunakan model modeling the way? Adakah pengaruh model pembelajaran modeling the way terhadap kemampuan menulis teks cerita fabel oleh siswa kelas VIII SMP?

\section{METODE}

Dalam penelitian ini peneliti mengguna-kan metode eksperimen, sedangkan bentuk desain yang digunakan adalah posttest-only control disgn (Arikunto, 2010). Metode eksperimen digunakan dengan maksud melihat akibat dari suatu perlakuan. Penelitian ini berupaya melihat pengaruh model pembelajaran modeling the way terhadap kemampuan menulis teks cerita fabel oleh siswa kelas VIII SMP Muhammadiyah 3 Medan tahun pembelajaran 2016/2017. Populasi penelitian ini adalah adalah siswa kelas VIII SMP Muhammadiyah 3 Medan yang berjumlah
50 orang yang tebagi dalam dua kelas. Satu kelas ditetapkan sebagai kelas eksperimen dan satu kelas sebagai kelas kontrol. Pengumpulan data dilakukan melalui tes hasil belajar. Data yang terkumpul dianalisis dengan statistik deskriptif dan statistik inferensial.

\section{HASIL DAN PEMBAHASAN}

Hasil postes kedua kelompok menunjukkan nilai tertinggi kelas eksperimen adalah 83, sedangkan nilai terendah 50. Nilai tertinggi kelas kontrol adalah 72, sedangkan nilai terendah 44. Rata-rata nilai postes kelas eksperimen adalah 70,28 dan rata-rata nilai postes kelas kontrol adalah 58,56. Dengan demikian dapat disimpulkan bahwa hasil belajar siswa yang diajar dengan menggunakan model pembelajaran modeling the way lebih tinggi dibandingkan dengan hasil belajar siswa yang diajar dengan menggunakan model konvensional.

Tabel 1. Nilai Posttest Siswa untuk Kelas Eksperimen

\begin{tabular}{ccccc}
\hline No & Nilai & Jumlah & \% & Katagori \\
\hline 1 & $80-100$ & 2 & $8 \%$ & Baik Sekali \\
2 & $66-79$ & 8 & $32 \%$ & Baik \\
3 & $55-65$ & 6 & $24 \%$ & Cukup \\
4 & $40-54$ & 3 & $12 \%$ & Kurang \\
5 & $<40$ & 6 & $24 \%$ & Gagal \\
\hline
\end{tabular}

Tabel 2. Nilai Posttest Sis wa untuk Kelas Kontrol

\begin{tabular}{ccccc}
\hline No & Nilai & Jumlah & $\%$ & Katagori \\
\hline 1 & $80-100$ & 2 & $8 \%$ & Baik Sekali \\
2 & $66-79$ & 6 & $24 \%$ & Baik \\
3 & $55-65$ & 4 & $16 \%$ & Cukup \\
4 & $40-54$ & 10 & $40 \%$ & Kurang \\
5 & $<40$ & 3 & $12 \%$ & Gagal \\
\hline
\end{tabular}

Setelah diketahui bahwa data hasil belajar kedua sampel berdistribusi normal dan homogen, selanjutnya analisis inferensial dengan menggunakan uji-t. Dari data diperoleh:

$\overline{\mathrm{X}_{1}}=70,28: \mathrm{SD}=10,00: \mathrm{SD}^{2}=100: \mathrm{N}=25$

$\overline{\mathrm{X}}_{2}=58,56: \mathrm{SD}=8,12: \mathrm{SD}^{2}=65,93: \mathrm{N}=25$ 


$$
\begin{aligned}
t_{\text {hitung }} & =\frac{X 1-\mathrm{X} 2}{\sqrt{\frac{s_{1}^{2}}{n_{1}}+\frac{s_{2}^{2}}{n_{2}}}} \\
& =\frac{70,28-58,56}{\sqrt{\frac{10,00}{25}}+\frac{8,12}{25}} \\
& =\frac{11,72}{\sqrt{0,4+0,3248}} \\
& =\frac{11,72}{\sqrt{0,7248}} \\
& =\frac{11,72}{0,85} \\
& =13,78
\end{aligned}
$$

Setelah dilakukan pengujian data hasil belajar, diperoleh nilai $t_{\text {hitung }}>t_{\text {tabel, }}$ yakni 13,78 > 1,78. Hasil tersebut mengindikasikan $\mathrm{H}_{0}$ ditolak dan $\mathrm{H}_{\mathrm{a}}$ diterima. Dengan demikian dapat disimpulkan bahwa hasil belajar siswa yang diajar dengan menggunakan menggunakan model pembelajaran modeling the way lebih tinggi dibandingkan dengan hasil belajar siswa yang diajar

\section{DAFTAR PUSTAKA}

Arikunto, Suharsimi. 2010. Prosedur Penelitian Suatu Pendekatan Praktik. Jakarta: Rineka Cipta.

Sudjana. 2008. Media Pengajaran. Bandung: dengan menggunakan model konvensional. Hal ini memiliki makna bahwa model pembelajaran modeling the way berpengaruh terhadap kemampuan menulis teks cerita fabel oleh siswa kelas VIII SMP Muhammadiyah 3 Medan Tahun Pembel-ajaran 2015-2016.

\section{PENUTUP}

Berdasarkan hasil penelitian diperoleh disimpulan: (1) kemampuan siswa menulis teks cerita fabel dengan menggunakan model pembelajaran modeling the way adalah baik, sedangkan kemampuan siswa menulis teks cerita fabel dengan menggunakan model konvensional berkategori kurang. Hasil belajar siswa yang diajar dengan menggunakan model pembelajaran modeling the way lebih tinggi dibandingkan dengan hasil belajar siswa dengan menggunakan model konvensional/ceramah. Hasil penelitian menunjukkan bahwa terdapat pengaruh yang signifikan model pembelajaran modeling the way terhadap kemampuan menulis karangan argumentasi oleh siswa kelas VIII di SMP.

Sinar Baru Algesindo.

Tarigan, H. G. 2005. Menulis sebagai Suatu Keterampilan Berbahasa. Bandung: Angkasa. 